\title{
The Effect of Instruction on Learners' Pragmatic Awareness: a Focus on Refusals
}

\author{
EVA ALCÓN SOLER \\ JOSEP GUZMÁN PITARCH ${ }^{*}$ \\ Universitat Jaume I
}

Received: 15 June 2010 / Accepted: 25 July 2010

\begin{abstract}
The benefits of instruction on learners' production and awareness of speech acts is well documented (see Alcón and Martínez-Flor, 2008, for a review of pragmatics in instructional contexts). However, few studies examine the influence that instruction may have on the cognitive processes involved in speech act production (FélixBrasdefer, 2008). In order to address this research gap, and taking into account the discussion in research on the concept of attention and related terms such as awareness (see Al-Hejin, 2004, for a review of the role of attention and awareness in second language acquisition research) this paper reports on the benefits of instruction on learners' attention and awareness during the performance of refusals. Thus, based on a pedagogical proposal for teaching refusals at the discourse level, we focus on the benefits that this pedagogical proposal can have on the information attended to during the planning and execution of refusals. Secondly, we explore whether instruction makes a difference in learners' awareness of refusals.
\end{abstract}

KEY WORDS: pragmatic awareness, refusals, interlanguage pragmatics, teaching pragmatics.

\section{RESUMEN}

El beneficio de la instrucción en la producción y la consciencia de los actos de habla se ha estudiado en diversos estudios (Alcón and Martinez-Flor, 2008). Sin embargo, muy pocos estudios analizan la influencia que de la instrucción en los procesos cognitivos que intervienen en la producción de los actos de habla (Félix-Brasdefer, 2008). Con la finalidad de abordar esta cuestión, y teniendo en consideración la discusión en torno a los conceptos de atención y consciencia (véase Al-Hejin, 2004, para una revisión de estos conceptos en el campo de la adquisición de segundas lenguas), el presente artículo analiza el beneficio de la instrucción en la atención y la consciencia pragmática durante el rechazo de peticiones. Después de exponer una propuesta pedagógica para enseñar a rechazar peticiones desde un punto de vista discursivo, se presentan los resultados de dicha propuesta en relación a la información a la que se presta atención durante la planificación y el rechazo de las peticiones. En segundo lugar, se analiza si dicha instrucción influye en la consciencia pragmática de dicho acto de habla.

PALABRAS CLAVE:

Consciencia pragmática, rechazar peticiones, pragmática el interlenguaje, enseñanza de la pragmática.

*Address for correspondence: Eva Alcón Soler and Josep Guzman Pitarch. Universitat Jaume I, Castellón, Spain. E-mail: alcon@ang.uji.es, guzman@trad.uji.es. 


\section{INTRODUCTION}

ILP research has focused on describing learners’ production, perception and acquisition of second language users' pragmatic ability. Among the different issues that have been considered, speech acts have been examined from a cross-cultural and a developmental perspective in different contexts. In educational contexts, learners' development of pragmatics has been addressed from different theoretical perspectives (see Alcón, 2008, for a review of cognitive and socially-oriented approaches to classroom research on pragmatics) and the factors that potentially influence pragmatic learning have been highlighted. Among those factors, the role of instruction on learners' awareness and production of speech acts has generated a lot of interest in the field of ILP. In this vein, work on the effect of instruction in relation to different speech acts (Olshtain and Cohen, 1990, on apologies; Rose and Ng KwaiFun, 2001, on compliments and compliment responses; Alcón, 2005; Codina, 2008; Martínez Flor, 2007; Safont, 2005, 2007; Salazar, 2007; Takahashi, 2001; Usó-Juan, 2007, on refusals) supports Schmidt's (1993, 1995, 2001) noticing hypothesis, and has provided evidence that high levels of attention-drawing activities are more helpful for pragmatic learning than exposure to positive evidence (see also Jeon and Kaya, 2006; and the collection of papers in Alcón and Martínez-Flor, 2005, 2008 and Rose and Kasper, 2001). In addition, results of studies dealing with the effect of instruction also seem to provide evidence on the superiority of explicit over implicit pragmatic intervention (see Takahashi, 2010, for a review of the effect of pragmatic instruction on speech act performance).

Following these research outcomes in the area of language pedagogy, suggestions are made for techniques and activities either to develop learners' pragmatic awareness about speech acts or to provide opportunities for speech act performance (see for instance the volumes by Bardovi-Harlig and Mahan-Taylor, 2003, and Tatsuki, 2005). Similarly, some pedagogical models have been suggested that aim to provide learners with the theoretical conditions for language learning, mainly adequate input, opportunities for output and feedback (Judd, 1999; Kondo, 2008; Martínez-Flor and Usó-Juan, 2006. See also MartínezFlor and Usó-Juan, 2010, for a review of different pedagogical proposals). Although we can claim that these pedagogical models offer learners opportunities for noticing, understanding and producing speech acts, two issues remain to be dealt with. The first one is related to the fact that speech acts are not presented in their sequential environment. Although conversation analysis-informed studies have shown that speech acts are not frequently concluded within an adjacency pair, most of the pedagogical proposals ignore the fact that speech acts such as refusals function as a response to an initiating act and they are co-constructed by two or more interlocutors over multiple turns. This is also mentioned by Kasper (2006), who points out 
that the interactive nature of conversation is absent in the teaching of speech acts. On that account, Félix-Brasdefer (2006) presents three pedagogical sessions for teaching the negotiation of refusals across multiple turns in Spanish. The first one, Communicative actions and cross-cultural awareness, focuses on cross-cultural awareness of refusing in English and Spanish, as well as providing pragmalinguistic input on refusals. In the second one, Doing conversation analysis in the classroom, the CA tools proposed by Pomeranz and Fehr (1997) are used to look at the boundaries of a refusal sequence, the realization of refusals across multiple turns, the initiating and ending of the refusal sequence, the strategies used to deliver the action, the taking of turns across the sequence, and the constructions of roles and identities of the interlocutors during the accomplishment of the speech act. Finally, in the last session, Communicative practice and feedback, learners produce refusals by means of role play activities and receive feedback from their peers.

The second issue that is worth considering is the fact that, in instructional contexts, it is difficult to provide learners with authentic pragmatic input. Different studies have examined the value of using video sequences to introduce pragmatics into the classroom. For instance, focusing on requests, Fernández-Guerra (2008) compares the occurrences of request head acts and peripheral modification devices in TV series and in spoken corpora. Results from this study show that, even though there are slight differences in some types of requests and their modifiers, requesting behaviour in TV series can be said to resemble genuine natural discourse and is thus a useful language resource with which to learn the speech act of requesting. Alcón (2007) and Martínez-Flor (2008) use film excerpts to examine the efficacy of instruction in learners' awareness of requests. In Alcón (2007) different excerpts from the TV series Stargate are used, together with explicit and implicit consciousness-raising tasks, to examine the benefits of pragmatic instruction. Results of the study confirm the value of employing video sequences to introduce pragmatics and the positive effects of instruction on learners' awareness of requests at both the noticing and the understanding levels. In the same vein, Martínez-Flor (2008) uses contextualised examples of request moves and role play situations that are similar to those occurring in film excerpts to raise learners' awareness on pragmalinguistic forms and sociopragmatic factors that influence different types of linguistic realizations in requests. Results from this instructional treatment indicate that learners make use of a higher number of internal and external modifiers as well as a wider variety of mitigating devices in their requestive behaviour.

Considering research outcomes on the benefits of instruction, the need to conduct pedagogical intervention at the discourse level (Félix-Brasdefer, 2006;Kasper, 2006) and the value of audiovisual input as a source of pragmatic input (Alcón, 2007; Fernandez-Guerra, 
2008; Martínez-Flor, 2008), the present study aims to answer the following research questions:

1. Is the teaching of refusals at the discourse level effective as regards the information attended to during the planning and execution of refusals?

2. Is the teaching of refusals at the discourse level effective as regards learners' awareness of refusals?

Considering the above research questions, two research hypotheses were formulated:

1. Hypothesis 1: The pedagogical intervention will increase the amount of pragmatic information attended to during the planning and execution of refusals.

2. Hypothesis 2: Learners' awareness of pragmalinguistics and sociopragmatics will increase after the instructional treatment.

\section{THE STUDY}

\section{II.1. Participants}

The study involved 99 students, all of them enrolled in the Degree in Translation at the university. Their ages ranged from 18 to 30 years old, the average age being 22.1 years. We excluded four participants for being bilingual in English/Spanish, two for having studied in a bilingual English/Spanish school during secondary education and one for having studied in an English-speaking environment for more than six months. The 92 students that finally participated in the study did not show any statistically significant differences in their level of proficiency in English, as measured by the university entrance exam they were required to pass in order to enrol on the translation degree. In addition, participants did not differ to any significant extent with regard to ethnicity or academic background. Two lecturers also participated in the study. While one of them focused on teaching refusals during two-hour sessions held every week for 6 weeks following the pedagogical proposal mentioned above, the other observed the lesson in order to indicate (should it be the case) any bias shown by the instructor for or against the instruction procedure and conducted verbal reports interviews on an individual basis before and after pragmatic instruction.

\section{II.2. Instructional treatment}

The pedagogical model employed in the present study can be used with different audiovisual sources and adapted to the teaching of different speech acts. The model involves four optional 
steps: Identifying refusals in interaction, Explaining the speech act set, Noticing and understanding refusal sequences, Negotiating and exploring learners' use of refusals (see Alcón, forthcoming, for a detailed explanation of the proposal). In the present study we focus on refusals, and scenes from the series Stargate were controlled for speech act type (refusals to requests) and social distance (+ power and social distance). In addition, since the present study aims to measure the effect of instruction on learners' attention and awareness of pragmatic issues, Step 1, Identifying refusals in interaction, Step 2, Explaining the speech act set, and Step 3, Noticing and understanding refusal sequences, were used during the instructional period.

Step 1, Identifying refusals in interaction is planned as a teacher-led activity in the classroom to make learners aware that speech acts are co-constructed by two or more interactants over multiple turns. Here, awareness-raising activities dealing with the coconstruction of refusals to requests over turns are used. Learners watch selected sequences from the series Stargate in English and transcripts are provided to identify the beginning and end of refusal sequences (see example 1).

\section{Example 1:}

FRASIER: General. Sorry to disturb you... I was wondering if I could have a word.

LANDRY: Of course, Doctor. Come in.

FRASIER: Thank you. Sir... I would like to make a request on behalf of all of the teams stranded in this reality. Please... postpone this mission until we can find a way to get home.

LANDRY: I can't do that. We need our teams out there gathering Intel on the Ori threat... instead of sitting on their hands here waiting for normal Gate operations to resume... and that won't be possible until this problem is dealt with.

FRASIER: While I can empathize sir... believe me. I think you need to take a look at the bigger picture... this goes beyond this world... beyond this galaxy... this universe... hundreds of billions of lives are at stake. Their survival could hinge on not just our return... but the return of every SG1 stranded on this base. Sir... back in my universe Earth is facing a global pandemic, one that your planet has already faced and beaten... you have the cure that could save my world, all I have to do is get it to them.

LANDRY: I can also empathize but at the risk of sounding callous... my priorities are with this world.

FRASIER: How can you prioritize the lives of one group over those of another? What makes my Earth any less important than your own?

LANDRY: We have the top minds from 18 different universes trying to get you home... now hopefully they can come up with a solution before this mission is completed but if they can't... then I'm sorry Doctor.

In addition, learners focus on the structure of the negotiation sequence by addressing the following questions:

1. In how may turns is the refusal sequence realized?

2. Is the refusal sequence realized directly or indirectly?

3. How is it initiated?

4. Who initiates the sequence? 
5. How do the interlocutors react to the initiating act?

6. How is the delay of the refusal accomplished?

7. Who finishes the sequence?

Step 2, Explaining the speech act set is also planned as a teacher-led activity in the classroom, and it aims to provide pragmalinguistic and sociopragmatic information related to the issue of directness and use of mitigation in the performance of refusals. Explicit instruction on the speech act set takes into account the power, social distance and degree of imposition involved in the situation. In addition, emphasis is placed on the way direct and indirect strategies are used in particular excerpts (see example 2 for indirect and 3 for direct ways of refusing) and the adjuncts that precede or follow the refusal in response to a request.

Example 2:

JACKSON: What are they doing?

TEAL'C: Preparing me for my death.

JACKSON: Oh.

TEAL'C: I would like to ask one final favour.

JACKSON: What is it?

TEAL'C: I would like to volunteer my lifeless body, and that of my symbiote, for your scientists to study. Perhaps you can better learn ways to battle the Goa'uld and the Jaffa.

JACKSON: Well, don't worry, Teal'c, there's not going to be any body to donate. Jack and Carter should be back any minute with the troops.

TEAL'C: Daniel Jackson. You must not allow Colonel O'Neill to deny the retribution the Byrsa deserve.

JACKSON: You know I have to admit, Teal'c, for once I agree with Jack. I mean, I respect your wishes, but I don't believe that you deserve to die.

Example 3:

MAYBOURNE: May I come in?

O'NEILL: No. I'm in no way obligated to put up with your crap any more.

MAYBOURNE: I think you're gonna want to hear what I have to offer you.

O'NEILL: Offer?

MAYBOURNE: May I sit down?

O'NEILL: No. You won't be here that long. What's this about?

Step 3, Noticing and understanding refusal sequences, focuses on drawing learners' attention to the performance of refusals from a discourse approach. In this vein, learners are encouraged to unload specific transcripts of the film excerpts of the Stargate series made available to them in a virtual classroom and explore some of the issues presented in steps 1 and 2 on their own. The following awareness-raising questions are provided while learners read the transcript of previously watched sequences of the series Stargate. 
1. Underline the lines where interlocutors negotiate a request. Is the request accepted?

2. Identify the negotiation sequence of the refusal

3. Circle how one of the interlocutors says no to the request

4. How many turns can you identify in the negotiated sequence?

5. Is the refusal realized directly or indirectly?

6. What language expressions are used?

7. Why do participants use these expressions?

8. Who initiates the sequence?

9. How do the other interlocutors react to the initiating act?

10. How is the delay of the refusal accomplished?

11. Who finishes the sequence?

12. Based on the interactional sequence, how would you describe the interlocutors' relationship?

The answers to these questions are provided for self-correction by learners. Finally, they watch the film sequence again.

\section{II.3. Data collection and analysis}

Retrospective verbal reports were used to examine the information attended to before and after receiving instruction. One lecturer conducted the pret-test and post-test interviews, which were controlled for speech act type (refusals to requests) and social distance (+ power and + social distance) and guided the students' retrospective verbal reports on an individual basis. In the pre-test interview, students were explained that the Department was going to organize a conference and wanted to ask students to register for the conference that was going to take place during the exam period. The lecturer was informed that attendance was not compulsory, but she also had to make three attempts to ask learners to participate in the conference. In addition, there was no possibility either to change the dates of the conference or to reduce the fees, since payment was compulsory for everybody. In the post-test interview, the student had to decide whether she/he could finally accept to participate in the conference. The lecturer was also informed to make three attempts to ask learners to accept the request for participation in the conference.

The recorded interviews were played back to each participant and they were asked to report what they were paying attention to when refusing the request. Responses were divided into linguistic, pragmalinguistic and sociopragmatic information attended to during the performance of refusals. Additionally, each learner was asked to explain and give reasons for 
his/her linguistic behaviour. Learners' explanations were coded as signs of linguistic, pragmatic and sociopragmatic awareness.

The sequence of data collection was as follows:

1. Pre-test recorded interview

2. Pre-test student's retrospective verbal report

3. Instructional treatment (two hour sessions over a period of six weeks)

4. Post-test recorded interview

5. Post-test student's retrospective verbal report

Finally, two researchers scored students' retrospective verbal reports on attention paid to pragmalinguistic, sociopragmatic and linguistic issues, as well as coded learners' explanation of their linguistic behaviour as sign of learners'pragmatic awareness before and after receiving instruction on refusals to requests.

\section{II.4. Results and discussion}

The information provided during participants' retrospective verbal reports was used to calculate learners' attention during the planning and execution of refusals. Thus, the variable attention was measured by asking learners what they were paying attention to during the pretest and post-test retrospective verbal reports. Attention was divided into linguistics (grammar, vocabulary, pronunciation), pragmalinguistics (finding a way to refuse the request), and/or sociopragmatics (mitigating the refusal taking into account contextual factors such as power of the interlocutor and social distance). As shown in Table 1, the mean of the information attended to in the pre-interview is lower (0.73) than the mean in the postinterview (1.67), and the range shows that while the distance in the pre-test is more than one point (0.22-1.43), in the post-test it is almost two points (0.99-2.75).

\begin{tabular}{|l|l|l|l|l|l|l|}
\hline \multirow{2}{*}{ Variable } & & & & & \multicolumn{2}{l|}{ Range } \\
\cline { 5 - 7 } & Mean & $\mathrm{N}$ & Std. Deviation & Std. Error Mean & Minimum & Maximum \\
\hline Attention-Pre & .7355 & 92 & .29442 & 0.0307 & .22 & 1.43 \\
Attention-Post & 1.6719 & 92 & .43265 & 0.0451 & .99 & 2.75 \\
\hline
\end{tabular}

Table 1. Differences as regards the information attended to in the pre-test and post-test interviews

In order to examine whether the differences in attention before and after pragmatic instruction are statistically significant we resorted to statistical tests. The KolmogorovSmirnov test retains the null hypothesis and confirms a normal distribution in our data $(p=$ 0.258 for the pre-test and $p=0.317$ for the post-test). Thus, we make use of parametric tests to see whether there are significant differences in learners' attention at two different moments (pre-test and post-test). Table 2 shows the results of a paired matched t-test, which reveal that 
the differences in attention before and after instruction are large enough to attribute them to random variations in scores. The $\mathrm{t}$ value $(\mathrm{t}=22.671)$ denotes statistically significant differences that point to a probability level of $p=0.000$.

\begin{tabular}{|c|c|c|c|c|c|c|c|c|}
\hline & \multicolumn{5}{|c|}{ Paired Differences } & \multirow[b]{3}{*}{$\mathrm{T}$} & \multirow[b]{3}{*}{ Df } & \multirow{3}{*}{$\begin{array}{l}\text { Sig. } \\
\text { (2-tailed) }\end{array}$} \\
\hline & \multirow[b]{2}{*}{ Mean } & \multirow{2}{*}{$\begin{array}{l}\text { Std. } \\
\text { Deviation }\end{array}$} & \multirow{2}{*}{\begin{tabular}{|l|} 
Std. Error \\
Mean
\end{tabular}} & \multicolumn{2}{|c|}{$\begin{array}{l}\text { 95\% Confidence } \\
\text { Interval of the } \\
\text { Difference }\end{array}$} & & & \\
\hline & & & & Lower & Upper & & & \\
\hline $\begin{array}{r}\text { Pair } 1 \text { Attention-pre } \\
\text { Attention-post }\end{array}$ & -.93641 & .39617 & .04130 & -1.01846 & -.85437 & -22.671 & 91 & .000 \\
\hline
\end{tabular}

Table 2. Differences in attention at the beginning and end of the instructional period

Thus, we can claim that Hypothesis 1 is confirmed, that is to say, pedagogical intervention will have an influence on the amount of information attended to during the planning and execution of refusals. Findings related to Hypothesis 1 seem to confirm previous research exploring instructional effects on learners' attention towards pragmatics (Alcón, 2007). In this study we measured whether participants showed changes in the information attended to before and after the instructional treatment and we can state that a cognitive change is observed as a result of the instruction. Findings related to Hypothesis 1 can be explained within the framework of Schmidt's (1990, 1993, 1994, 1995, 2001) Noticing Hypothesis. Our results seem to indicate that instruction does make a difference in drawing learners' attention towards target pragmatic issues - in this particular case, in relation to the speech act of refusals. Thus, in line with previous research, the present study also seems to confirm awareness-raising as an approach to the teaching of pragmatics.

Moreover, in order to examine changes in the information attended to during the planning and execution of refusals in the pre-tests and post-tests, the information reported in the retrospective verbal reports was classified into pragmalinguistic, sociopragmatic and linguistic information. As illustrated in Figure 1, learners in the pre-test interview, that is to say before receiving the instruction, focus their attention on linguistic issues 95 times, followed by 76 instances of sociolinguistic attention and 35 pragmalinguistic comments. However, after receiving instruction there is a decrease in the amount of attention paid to linguistic aspects (55), a greater number of comments reporting their attention to pragmalinguistic (235) and sociopragmatic issues (176). 


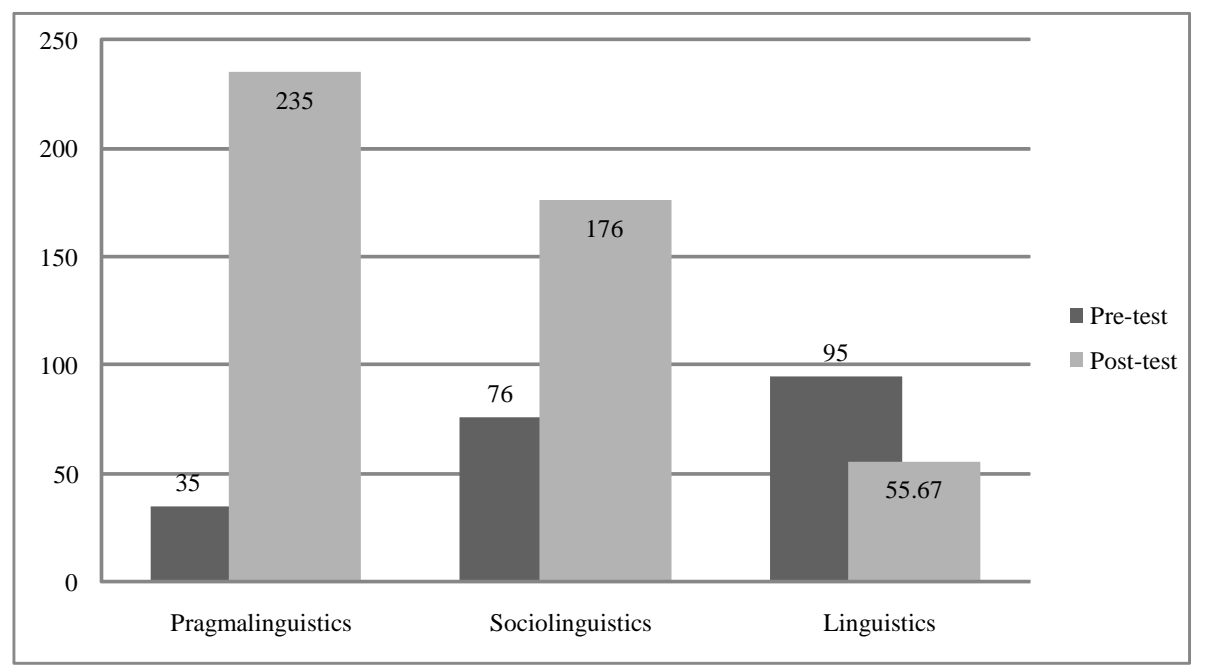

Figure 1. Learners' attention to pragmalinguistic, sociopragmatic and linguistic issues in the pre-test and the post-test interviews

In relation to Hypothesis 2, which claims that learners' awareness towards pragmalinguistics and sociopragmatics would increase after the instructional treatment, a detailed analysis of learners' explanations of their verbal behaviour before and after the instructional period was carried out. The variable awareness accounted for the total number of learners' explanations of their linguistic behaviour. Here, we can observe some examples of learners' responses to the question "Why did you say that?” during the retrospective verbal reports:

a) Pragmalinguistic information:

“I was thinking a good reason to say no” (pre-test retrospective report)

"I wanted to say no indirectly and be polite" (post-test retrospective report)

b) Sociopragmatic information:

"I did not want to apply for the conference but she was the teacher and I was trying to find a way not to offend her" (pre-test retrospective report)

"The status of the professor forces me to make up a good excuse" (post-test retrospective report)

c) Linguistic information:

"I was thinking how to say I didn't have the money" (pre-test retrospective report)

"I knew the verb was not correct and I changed it” (post-test retrospective report)

“I couldn’t remember how to pronounce fees” (pre-test verbal report) 
The total number of responses was divided into partitions and the frequency distribution of the scores was calculated as follows:

1. Awareness during the pre-test interviews $=(0.33 *$ Pragmalinguistics $+0.33 *$ Sociopragmatics $+0.33 *$ Linguistics)

2. Awareness during the post-test interviews $=(0.33 *$ Pragmalinguistics $+0.33 *$ Sociopragmatics $+0.33 *$ Linguistics)

In relation to pragmalinguistics, the percentage of participants that do not refer to pragmalinguistic issues in the pre-test (62\%) or refer to it only once (38\%) contrasts with findings in the post-test interview where all the participants comment on pragmalinguistics issues: $2.2 \%$ refer to them once, $45.7 \%$ twice, $46.7 \%$ three times and $5.4 \%$ four times. Similar patterns can be observed in relation to sociopragmatic awareness. The frequency distribution of sociopragmatic comments in the pre-test and post-test interviews shows that learners' awareness of sociopragmatics in the post-test differs with regards to the pre-test. The percentage of participants that ignore sociopragmatic issues in the pre-test verbal report (22\%) or refer to them only once (71\%) contrasts with findings in the post-test verbal reports, where all the participants explain their verbal behaviour in relation to sociopragmatic issues: $35.9 \%$ refer to them once, $44.6 \%$ twice, $13 \%$ three times and. $6.51 \%$ more than four times

Thus, we can claim that learners' awareness of pragmalinguistics and sociopragmatics increases after the instructional treatment. In contrast, learners' concern for linguistic issues was higher in the pre-test than in the post-test (the mean of the linguistic information attended to in the pre-test retrospective verbal report being 0.73 and 0.59 in the post-test). In order to examine whether the differences in awareness are significant we resorted to statistical tests. The Kolmogorov-Smirnov test rejects the null hypothesis and the Wilcoxon Signed Ranks test denotes that there are significant differences in learners’ pragmatic awareness before and after the instructional period (see Table 3).

\begin{tabular}{|l|l|l|l|l|l|l|l|}
\hline & N & Minimum & Maximum & Mean & Std. Deviation & & $\begin{array}{l}\text { Asymp. Sig. } \\
\text { (2-tailed) }\end{array}$ \\
\hline Pre-Pragma & 92 & 0 & 1 & .38 & .488 & $-8.383^{\mathrm{a}}$ & .000 \\
Post-Pragma & 92 & 1 & 4 & 2.55 & .635 & & \\
Pre-Socio & 92 & 0 & 2 & .83 & .505 & $-7.563^{\mathrm{a}}$ & 000 \\
Post-Socio & 92 & 1 & 5 & 1.91 & .898 & & \\
Pre-Linguist & 92 & .33 & 1.65 & 1.0223 & .40063 & $-6.447^{\mathrm{b}}$ & 000 \\
Post-Linguist & 92 & .00 & 1.65 & .5990 & .38500 & \\
\hline
\end{tabular}

a. Based on negative ranks. B. Wilcoxon Signed Ranks Test

Table 3. Differences in pragmalinguistic, sociopragmatic and linguistic awareness at the beginning and end of the instructional period. 
As shown in table 3, we can state that Hypothesis 2 is confirmed and that instruction seems to be effective in drawing learners' attention to explicit knowledge of refusal strategies (pragmalinguistic knowledge) in relation to context (sociopragmatic knowledge). Another issue that is worth mentioning is that, in the post-test retrospective verbal reports, learners report that they are aware of their lack of linguistic knowledge to refuse politely. Thus, even if their original intention was to give opinions or alternatives rather than to refuse directly or avoid being involved in a negotiation sequence, they claim that they do not know how to do it. This can be observed in the following examples, suggesting the need for further exploration of the relationship between linguistic and pragmatic competence (see also Martí, 2008):

“I wanted to say 'no' politely, but I couldn’t find a way”

"At this point I tried not to be rude, but I also wanted not to go to the conference. So, I tried, but did not know how and decided to make it clear that I could not participate”

These last comments during the post-test retrospective verbal protocols are absent in the pre-test, suggesting that the instruction of refusals at the discourse level may have influenced learners' awareness of pragmatics and interpersonal skills, even though they still need to work on their linguistic competence. Focusing on interpersonal skills, although this was not the object of analysis in the present study, we observed that most learners understand communication as a one-way process in the pre-test interview, that is to say, before receiving instruction on refusals at the discourse level. Yet, this view is modified towards understanding communication as a two-way process in the post-test. This is illustrated by learners' attention to interpersonal issues in the post-test, above all the interlocutor's feelings and the hearer's approval and concern for new information.

Examples of responses when they explain why they refuse in the pre-test interview:

"I didn't want to go, so I said that"

"I couldn’t understand why I should participate so I asked him why"

Examples of responses when they explain why they refuse in the post-test interview:

"I was thinking of an excuse so he couldn't feel I did not want to accept"

"I wanted to show that I appreciated the information and that I was interested in the proposal but I couldn't during the exam period"

"Well, that was new for me. I never thought about this possibility, but I did not want to say no from the beginning and asked her for further information"

The results of the present study must be understood within the three underlying concepts that guided the pedagogical intervention. These are the concepts of intention, attention and awareness. In the first case, intention includes the fact that the aim of the instruction was to teach the speech act of refusals from a discourse approach, and results must be understood in relation to intentional learning. We acknowledge that different results might have been obtained in other contexts where language-learning occurs incidentally. Secondly, 
the dimension of attention refers to verbally reporting the detection of linguistic, pragmalinguistic or sociolinguistic issues during the planning and execution of refusals. In order words, it accounts for drawing learners' attention, which means noticing the target form. Thirdly, participants' explanations of their verbal behaviour in relation to linguistic knowledge (tense aspects, lexical words) or pragmatic knowledge (such as power, status or social distance of the interlocutor) was understood as awareness at the level of understanding and as a sign that explicit learning was taking place. It is important to consider this since incidental learning or awareness only at the level of noticing rather than at the level of understanding might have shed different results. In the present study, we focused on the effect of explicit and deductive approaches to teaching pragmatics and more specifically on how these approaches, together with consciousness-raising tasks, seem to be an effective way to help learners gain in awareness of refusals. However, different attention-drawing activities may shed different results regarding the benefit of pragmatic instruction in language learning contexts.

\section{Conclusion}

Findings from the present study show the benefits of pragmatic instruction on learners' attention and awareness of the pragmalinguistic and sociopragmatic issues involved in the production of the speech act of refusals. Thus, and in line with previous research, the present study supports the claims that instruction makes a difference in the pragmatic realm (Kasper and Rose, 2002; see also Jeon and Kaya, 2006; and the collection of papers in Alcón and Martínez-Flor, 2005, 2008 and Rose and Kasper, 2001). Furthermore, some pedagogical insights can be drawn from the study. Firstly, planned pedagogical actions seem likely to work in teaching pragmatics in EFL contexts. It seems that providing learners with opportunities for audiovisual pragmatic input, awareness and comprehension of different pragmatic meanings, together with opportunities to work with pragmatic consciousnessraising tasks, makes a difference in learners' awareness of refusals. Secondly, teaching the speech act of refusals at the discourse level may indirectly help to focus on other conversational skills such as turn taking or negotiation strategies that are often neglected in pragmatic instruction, which is mostly concerned with the teaching of speech acts.

In spite of the benefits of instruction on learners' pragmatic awareness, care should be taken not to generalize results from this study. It is not possible to take the participants reports as signs of their implicit pragmatic competence in interaction, since verbal reporting is a very different activity from engaging in a refusal sequence as a social practice. Besides, individual 
differences, such as bilingualism or gender have not been considered in the present study. Although Catalan was a second language for the participants and both male and female learners took part in the study, these two variables have not been analysed. However, given the above-mentioned findings relating pragmatic instruction at the discourse level to an increase in attention to interpersonal issues, further analysis of the data might shed light on whether particular characteristics of language learners in multilingual contexts (Todeva and Cenoz, 2009) can have an influence on interpersonal communication skills.

Moreover, the research methodology adopted in the present study may trigger further research on pragmatic awareness. Most ILP studies dealing with the role of instruction to draw learners' attention to pragmatics assess what is attended to by means of post-test tasks such as discourse evaluation tests. In the present study, following cognitive psychology (Schmidt, 2001; Tomlin and Vila, 1994), first person accounts, despite their subjectivity, have been used to assess whether learners are able to consciously attend to the pragmatic information provided during the instruction. Finally, in line with Safont's (in press) proposal for analyzing pragmatic competence in multilingual contexts, further research may resort to the adoption of interactionist research methods to examine whether cognitive changes are observed as a results of pragmatic instruction. This particular instruction may also be analysed in relation to gains in learners' production of refusals, which would lead us to compare learners' gains in awareness and realization of refusals following the pedagogical proposal outlined in this paper.

\section{ACKNOWLEDGEMENT}

We are grateful to the two blind reviewers and valuable comments and suggestions for improvement.

\section{NOTES}

This study is part of a research project funded by (a) the Spanish Ministerio de Ciencia e Innovación (FFI2008-05241/FILO); b) FFI2009-09544 / HUM2006del with FEDER funds from the European Union and (c) Fundació Universitat Jaume I and Caixa Castelló-Bancaixa (08I447.01/1); d) P11B2008-59.

\section{REFERENCES}

Alcón, E. (2005). Does instruction work for pragmatic learning in EFL contexts? System, 33(3), 417435.

Alcón, E. (2007). Fostering EFL learners' awareness of requesting through explicit and implicit consciousness-raising tasks. In M. P. García Mayo (Ed.), Investigating tasks in formal language learning (pp. 221-241). Clevedon: Multilingual Matters.

Alcón, E. (2008). Investigating pragmatic language learning in foreign language classrooms. International Review of Applied Linguistics, 46, 173-196.

Alcón, E. (forthcoming). A pedagogical proposal for teaching speech acts at the discourse level: Its effects on learners' production of refusals. 
Alcón, E. \& Martínez-Flor, A. (Eds.). (2005). Pragmatics in instructed language learning. System, 33(3) (Special issue).

Alcón, E. \& Martínez-Flor, A. (Eds.). (2008). Investigating Pragmatics in Foreign Language Learning, Teaching and Testing. Clevedon: Multilingual Matters.

Al-Hejin, B. (2004). Attention and awareness: Evidence from cognitive and second language acquisition research. Working papers in TESOL and Applied Linguistics, 4(1), 1-22.

Bardovi-Harlig, K. \& Mahan-Taylor, R. (2003). Teaching Pragmatics. Washington D.C.: US Department of State Office of English Language Programs.

Codina, V. (2008). The immediate vs. delayed effect of instruction on mitigators in relation to the learner's language proficiency in English. In E. Alcón (Ed.), Learning how to request in an instructed language learning context (pp. 227-256). Bern: Peter Lang.

Felix-Brasdefer, C. (2006). Teaching the negotiation of multi-turn speech acts: using conversationanalytic tools to teach pragmatics in the FL classroom. In K. Bardovi-Harlig, J. C. FelixBrasdefer \& S. O. Alwiya, (Eds.), Pragmatics Language Learning, 11, 165-198.

Félix-Brasdefer, J. C. (2008). Perceptions of refusals to invitations: Exploring the minds of foreign language learners. Language Awareness, 17(3), 195-211.

Fernandez-Guerra, A. (2008). Requests in TV series and in naturally occurring discourse: A comparison. In E. Alcón (Ed.), Learning how to request in an instructed language learning context (pp. 11-126). Bern: Peter Lang.

Jeon, E. H. / Kaya, T. (2006). Effects of L2 Instruction on Interlanguage Pragmatic Development. In J. M. Norris \& L. Ortega (Eds.), Synthesizing Research on Language Learning and Teaching (pp. 165-211). Amsterdam: John Benjamins.

Judd, E. (1999). Some issues in the teaching of pragmatic competence. In E. Hinkeñ (Ed.) Culture in second language teaching and learning (pp. 152-166). Cambridge: Cambridge University Press.

Kasper, G. \& Kenneth R. (2002). Pragmatic development in a second language. Oxford, UK: Blackwell.

Kasper, G. (2006). Speech acts in interaction: Towards discursive pragmatics. In K. Bardovi-Harlig, C. Félix-Brasdefer \& A. S. Omar (Eds.), Pragmatics and language learning, 11 (pp. 281-314). Honolulu, HI: National Foreign Language Resource Center, University of Hawai'I at Manoa.

Kondo, S. (2008). Effects on pragmatic development through awareness-raising instruction: Refusals by Japanese EFL learners. In E. Alcón and A. Martínez-Flor (Eds.), Investigating pragmatics in foreign language learning, teaching and testing (pp. 153-177). Clevedon: Multilingual Matters.

Martí, O. (2008). Grammatical and pragmatic competence in EFL contexts: Do they really go hand in hand? In E. Alcón (Ed.), Learning how to request in an instructed language learning context. (pp. 163-190). Bern: Peter Lang.

Martínez Flor, A. (2008). The effect of inductive-deductive teaching approach to develop learners' use of request modifiers in the EFL classroom. In E. Alcón (Ed.), Learning how to request in an instructed language learning context (pp. 191-226). Bern: Peter Lang.

Martínez-Flor, A. \& Usó-Juan, E. (2006). A comprehensive pedagogical framework to develop pragmatics in the foreign language classroom. The 6Rs approach. Applied Language Learning, 16, 39-64.

Martínez-Flor, A. \& Usó-Juan, E. (Forthcoming). The teaching of speech acts in second and foreign language instructional contexts. In A. Trosborg (Ed.), Handbook of pragmatics. Berlin: Mouton de Gruyter.

Martínez-Flor, A. (2007). Analysing request modification devices in films: Implications for pragmatic learning in instructed foreign language contexts. In E. Alcón \& M. P Safont (Eds.), Intercultural language use and language learning (pp. 245-280). The Netherlands: Springer.

Olshtain, E. \& Cohen, A. D. (1990). The learning of complex speech act behavior. TESL Canada Journal, 7(82), 45-65.

Pomerantz, A \& Fehr, B. J. (1997). Conversation analysis: An approach to the study of social action as sense making practices. In T. A. van Dijk (Ed.), Discourse as social interaction, Discourse Studies: A Multidisciplinary Introduction (pp. 64-91). London: Sage Publications.

Rose, K. R. \& G. Kasper (Eds.). (2001). Pragmatics in Language Teaching. Cambridge: Cambridge University Press. 
Rose, K. R. \& Ng Kwai-fun, C. (2001). Inductive and deductive approaches to teaching compliments and compliment responses. In R. R. Kenneth and G. Kasper (Eds.), Pragmatics in Language Teaching (pp. 145-170). Cambridge: Cambridge University Press.

Safont, M. P. (2005). Third Language Learners. Pragmatic Production and Awareness. Clevedon: Multilingual Matters.

Safont, M. P. (2007). Pragmatic production of third language learners: A focus on request external modifications. In E. Alcón \& M. P. Safont (Eds.), Intercultural Language Use and Language Learning (pp. 167-189). Amsterdam: Springer.

Safont, M. P. (in press). Pragmatic competence in multilingual contexts. In The Encyclopedia of Applied Linguistics. John Wiley and Sons.

Salazar, P. (2007). Examining mitigation in requests: A focus on transcripts in ELT coursebooks. In E. Alcón \& M. P. Safont (Eds.), Intercultural Language Use and Language Learning (pp. 207222). Amsterdam: Springer.

Schmidt, R. (1993). Consciousness, learning and interlanguage pragmatics. In G. Kasper and S. BlumKulka (Eds.), Interlanguage Pragmatics (pp. 21-42). New York: Oxford University Press.

Schmidt, R. (1995). Consciousness and foreign language learning: A tutorial on the role of attention and awareness in learning. In R. Schmidt (Ed.), Attention and Awareness in Foreign Language Learning (pp. 1-63). Honolulu: University of Hawai'i, Second Language Teaching and Curriculum Center.

Schmidt, R. (2001). Attention. In Peter Robinson (Ed.), Cognition and Second Language Instruction (pp. 3-33). New York: Cambridge University Press.

Takahashi, S. (2001). The role of input enhancement in developing pragmatic competence. In R. R. Kenneth \& G. Kasper (Eds.), Pragmatics in Language Teaching (pp. 171-199). Cambridge: Cambridge University Press.

Takahashi, S. (2010). The effect of pragmatic instruction on speech act performance. In A. MartínezFlor \& E. Usó-Juan (Eds.), Speech Act Performance. Theoretical, empirical and methodological issues (pp. 127-144). Amsterdam: John Benjamins.

Tatsuki, D. (Ed.). (2005). Pragmatics in language learning, theory and practice. Tokyo: JALT, The Japan Association for Language Teaching, Pragmatics Special Interest Group.

Todeva, E \& Cenoz, J. (2009). The multiple realities of multilingualism. Berlin: Mouton de Gruyter.

Tomlin, R. S. \& Villa, V. (1994). Attention in cognitive science and second language acquisition. Studies in Second Language Acquisition, 16, 183-203.

Usó-Juan, E. (2007). The presentation and practice of the communicative act of requesting in textbooks: Focusing in modifiers. In E. Alcón \& M. P Safont (Eds.), Intercultural language use and language learning (pp. 223-244). The Netherlands: Springer. 